\title{
International Development Solutions by Discussion and Publication
}

\author{
U. Ibrahim Ali, Zumarthfarazana \\ Research of International Development Solutions \\ Research Associate
}

\begin{abstract}
Now 400 millions research papers are available for peace Solution, but there is no result for the it, unless the messages Posted in the website http://www.goldenduas.com are researched by researchers all over the world. Otherwise the world cannot have peace and Unity for some reasons or the other. Thank you very much for joining me in the interest of public, Safety And Peace. Most of the followers are researchers And good educated persons involving peace, Unity and safety amongst all Communities in the world and accordingly we sought support from all of You to study and analyze the God's messages posted in the website www.goldenduas.com and it may be advertised all over the world on The reasons that every person are suffering are due to all kind of Natural calamaties in the world. God's messages are posted in the Website www.goldenduas.com are followed, otherwise No government and Scientists can safeguard life and liberty of the public of the all communities in the world according to Quranic verses 17:16 and 28:59.Internet services in the world are requested to support us to spread our website messages to each and every corner of the world to know and discuss by all the internet communities in the world.
\end{abstract}

Holy Bible says:

1."Behold, I send you forth as sheep in the midst of wolves: be ye

There fore wise as serpents, and harmless as doves".

- Matthew 10:16.

2."Be strong, do not fear; your God will come, he will come with vengeance;

with divine retribution he will come to save you". - Isaiah 35:4

Holy Quran says:

28:59. Nor was thy Lord the one

To destroy a population until

He had sent to its Centre

An apostle, rehearsing to them

Our Signs; nor are We

Going to destroy a population

Except when its members

Practice iniquity.

Our website http:www.goldenduas.com contains more information not only to avoid all kinds of natural calamities in the world but also to 12:15 improve economic growths in business, education, employment, jobs, health, wealth, security, faith, climate changes (heavy snow, rain, heat etc), and causes unity and peace all over the world. Our service all over the world is a non-profitable service to all mankind and animals.

\section{Introduction:}

We are researching how world will solve all the world challenges and dispute between all other communities and accordingly, we have prepared the following research report to solve all the problems in the world by research, discussions and publications to obtain opinions from all other leaders and scholars in the world. Our service in the world is non-profitable in the interest of public in the world.

\section{Discussion to bring co-operation between Jewish, Christianity \& Muslims in the world}

We recently published book in Hindi language, not the essence. India had a great kalanku shook the book appeared .

However, Kalki Avatar engaged in the research, this book is a " universal " iraittut guide, came from Bengal . This is an important evidence in Allahabad University . The writing, outstanding Sanskrit scholar Pandit light pantittavar holds a Brahmin .

Pandit eight Hindu scholars is the same as submitting for review, Prakasa, pannetunkala research and unrelenting hard work has produced . They are completely patittunarntu book, strong atarankalin, the message of the book is fully attest to that fact . 
Travel guide who was born in Mecca, Kalki Avatar, referring to the great scriptures of India , Muhammad ( peace be upon him peace be upon him ) mamanitare is. End of life to embrace Islam if God's final messenger to iraipaniyarriya, Hinduism, Kalki Avatar, now a thousand four hundred years ago, waiting for one , he emerged with iraittutai direction. Presents evidence from Scripture sovereignty, Pt, to prove his thesis .

Testimonials :

1. Vedas, Kalki Avatar, the last messenger of God says . It is the last messenger, Muhammad is the case can be resolved .

2 . According to forecasts of the Hindu scriptures, the incarnation of Kalki will take place surrounded by water . It says " " Arab jasirattul tipakarpamakum is surrounded by the Arabian Sea .

3 . Hindu sacred texts, the father, mother and Kalki Avatar of Vishnu Bhagat said that comanip . If Sanskrit Vishnu, God, Allah means . Also, if it means faithful servant .

Thus, Vishnu Bhagat, ie slave of Allah in Arabic, the word is Abdullah . The Sanskrit word quiet peaceful means comanip. The concept of the meaning of the same word in Arabic. Thus, the final Messenger Muhammad Abdullah has strengthened the concept of parents .

4. Well, Kalki Avatar, olives and live there perittankanikalai, to be honest word Hindu is in regular books . Therefore, it is true in the case of Muhammad writes scholar light .

5. The Vedas say that the highest values of humanity birth of Kalki Avatar. Again, the highest, was born in a respectable family, Quraysh, Muhammad is precisely the case .

6. Kalki Avatar, the peon wisdom of God in a cave that was available. Thus, makkavileye, Jibreel Muhammad is the Messenger of Allah ( peace be upon him, peace be upon him ) was the only one illuminated by Hira Cave .

7. Well , Kalki Avatar is for God's help. These routes Prophet Muhammad peace be upon him avarkalaittavira talk to someone else ?"

According to Torah \& Holy Bible verses Deut 18:18 as follows "I will raise up for them a prophet like you from among their fellow Israelites, and I will put my words in his mouth. He will tell them everything I command him. Deut 21:21 as follows "Then all the men of his town are to stone him to death. You must purge the evil from among you. All Israel will hear of it and be afraid". Psalm 118:22-23 as follows 118:22, The stone which the builders refused is become the head stone of the corner. 118:23, This is the LORD'S doing; it is marvellous in our eyes. Isaiah 4:1-13 as follows " 1 , Here is my servant, whom I uphold, my chosen one in whom I delight; I will put my Spirit on him, and he will bring justice to the nations. 2, He will not shout or cry out, or raise his voice in the streets. 3, A bruised reed he will not break, and a smouldering wick he will not snuff out. In faithfulness he will bring forth justice; 4, He will not falter or be discouraged till he establishes justice on earth. In his teaching the islands will put their hope." 5, This is what God the Lord says - the Creator of the heavens, who stretches them out, who spreads out the earth with all that springs from it, who gives breath to its people, and life to those who walk on it: 6, "I, the Lord, have called you in righteousness; I will take hold of your hand. I will keep you and will make you to be a covenant for the people and a light for the Gentiles, 7, To open eyes that are blind, to free captives from prison and to release from the dungeon those who sit in darkness. 8, "I am the Lord; that is my name! I will not yield my glory to another or my praise to idols. 9, See, the former things have taken place, and new things I declare; before they spring into being I announce them to you." 10 , Sing to the Lord a new song, his praise from the ends of the earth, you who go down to the sea, and all that is in it, you islands, and all who live in them. 11 Let the wilderness and its towns raise their voices; let the settlements where Kadar lives rejoice. Let the people of Selah sing for joy; let them shout from the mountaintops. 12 Let them give glory to the Lord and proclaim his praise in the islands. 13 The Lord will march out like a champion, like a warrior he will stir up his zeal; with a shout he will raise the battle cry and will triumph over his enemies. Habakkuk 3:3-4 3:3 God came from Teman, and the Holy One from Mount Paran. Selah His splendor covered the heavens, and the earth was full of his praise. 3:4 His brightness was like the light; rays flashed from his hand; and there he veiled his power. Matthew 21:42-43 21:42 Jesus said to them, "Have you never read in the Scriptures: "The stone that the builders rejected has become the cornerstone; [a] this was the Lord's doing, and it is marvelous in our eyes'? 21: 43 Therefore I tell you, the kingdom of God will be taken away from you and given to a people producing its fruits. John 14:12-17, 26, 28 12, Verily, verily, I say unto you, He that believeth on me, the works that I do shall he do also; and greater works than these shall he do; because I go unto the Father. 13 And whatsoever ye shall ask in my name, that will I do, that the Father may be glorified in the Son. 14 , If ye shall ask me anything in my name, that will I do. 15 , If ye love me, ye will keep my commandments. 16, And I will pray the Father, and he shall give you another Comforter, that he may be with you forever, 17 , even the Spirit of truth: whom the world cannot receive; for it beholdeth him not, neither knoweth him: ye know him; for he abideth with you, and shall be in you. 26, But the Comforter, even the Holy Spirit, whom the Father will send in my name, he shall teach you all things, and bring to your remembrance all that I said unto you. 28 , Ye heard how I said to you, I go away, and I come unto you. If ye loved me, ye would have rejoiced, because I 
go unto the Father: for the Father is greater than I. John 16: 7-14 16:7, But very truly I tell you, it is for your good that I am going away. Unless I go away, the Advocate will not come to you; but if I go, I will send him to you. 8, When he comes, he will prove the world to be in the wrong about sin and righteousness and judgment: 9, about sin, because people do not believe in me; 10, about righteousness, because I am going to the Father, where you can see me no longer; 11, and about judgment, because the prince of this world now stands condemned. 12, "I have much more to say to you, more than you can now bear. 13, But when he, the Spirit of truth, comes, he will guide you into all the truth. He will not speak on his own; he will speak only what he hears, and he will tell you what is yet to come. 16:14, He will glorify me because it is from me that he will receive what he will make known to you. ---------- In the above verses it is revealed that after Jesus, every Christians and Jewish shall follow prophet Muhammad as prophet, but it is revealed that there exists in the Torah \& Gospel even after the original text has been distorted clear prophecies indicating the coming of prophet Muhammad on the reasons revealed in the Holy Quran verses 4:47 As follows "O you who were given the Scripture, believe in what We have sent down [to Muhammad], confirming that which is with you, before We obliterate faces and turn them toward their backs or curse them as We cursed the sabbath-breakers. And ever is the decree of Allah accomplished". 7:157 " Those who follow the Messenger, the unlettered prophet, whom they find written in what they have of the Torah and the Gospel, who enjoins upon them what is right and forbids them what is wrong and makes lawful for them the good things and prohibits for them the evil and relieves them of their burden and the shackles which were upon them. So they who have believed in him, honored him, supported him and followed the light which was sent down with him - it is those who will be the successful". 61:06 "And [mention] when Jesus, the son of Mary, said, "O children of Israel, indeed I am the messenger of Allah to you confirming what came before me of the Torah and bringing good tidings of a messenger to come after me, whose name is Ahmad." But when he came to them with clear evidences, they said, "This is obvious magic." Circumstances stated above all the Rabbi's \& Christian monks who devour the wealth of mankind in falsehood and hinder from the way of Allah and those who hoard up gold and silver of which has not in the way of Allah announced to them a painful torment and these facts have to be discussed by everyone of Christians, Jewish \& Muslims in the world otherwise world will not bring co-operation between these Communities/ Religions till a Day of Resurrection. To Stop Terrorism and all troubles in the world in accordance with Quran verse 08:73 as follows "And those who disbelieve are allies of one another (and) if you (Muslims of the whole world collectively) do not do so [i.e. become allies as one united block under on Khalifa (a chief Muslim ruler for the whole Muslim world) to make victorious Allah's religion of Islamic Monotheism], there will be Fitnah (wars, battles, polytheism) and oppression on the earth and great mischief and corruption (appearance of polytheism)". Note: It has been mentioned in Tafsir at Tabari that the best interpretation of this verse 08:73 is that if you do not do what we (Allah) have ordered you to do [i.e. all of you (Muslims of the whole world) do not become allies as one united block to make Allah's religion (Islam) victorious there will be great Fitnah(polytheism, wars, battles, killings, robbing, a great mischief, corruption and oppression etc)] And it is Fitnah to have many Khalifa (Muslim rulers) as it has been mentioned in Shahih Muslim by “Arfajah, who said: I heard Allah's messenger saying: "when you all (Muslims) are united (as one block) under a single separate you into different groups, then kill that man. The extract of above said Al- Quran verse 08:73 is to obey Almighty's words and follow Muhammad's order and opinion that not to have a single or multiple Khalifa (A single Muslim ruler for the whole Muslims) in the world if we do so that would be a sin (mistake or act against the Holy Quran, Almighty God Allah \& Prophet Muhammad's words) we are already been warned misbelievers may not enter Jannath, by accepting a Muslim ruler we indeed support the sin against kids, women, and old aged peoples, which are not the deeds of pure Muslim as defined by Almighty and Prophet Muhammad (sal-a-wasm). So all say us that Khalifah / Muslim ruler or any kind of representing in the name of federation, assassination, centres and organisation and also so called Jamath in the world. Now Syria, Libya, Palestine, Pakistan, Turkey, Afghanistan, Egypt, Sudan, South Sudan, Iran, Iraq, Somalia, Nigeria \& All other Muslim countries are facing Fitnah (trouble) against Muslims and other communities living there in to create terrorism etc and the same are proved in accordance with Quran verse 05:33 as follows "Indeed, the penalty for those who wage war against Allah and His Messenger and strive upon earth [to cause] corruption is none but that they be killed or crucified or that their hands and feet be cut off from opposite sides or that they be exiled from the land. That is for them a disgrace in this world; and for them in the Hereafter is a great punishment" in view of the above said facts and circumstances it is highlighted that all the rulers of Muslim countries and also representing various forums, federations, centres, organisations and Jamaths in the world are the recompense of those who wage war against Allah and his messenger ( $\mathrm{Sal}-\mathrm{a}$ - wasl) and do mischief in the land is only that they shall be killed or crucified or their hands and their feet be cut off from opposite sides, or be exiled from the land that is their disgrace in this world, and a great torment is theirs in Hereafter. These are the punishments in the world by God" after the day of Resurrection they have to punish severely. All the government have no other option except "BAN" all the Muslim organisation, federation, forums, associations, centres \& Jamaths if the Governments are feeling to stop terrorists activities all the troubles created by most of the Muslims in the world. Please visit and view the 
$\begin{array}{lllll}\text { messages } & \text { poster } & \text { our } & \text { facebook } & \text { page }\end{array}$ http://www.facebook.com/researchofInternationaldevelopmentsolutions .

Your success

U. Ibrahim Ali

Researcher International development solutions

\section{Amicable Solutions Between Christians, Jewish, Hindu AND Muslims In The WORLD}

1. World Piece

2. World Unity

3. Economic Solutions

\section{WORLD PIECE AND UNITY}

Now all the communities in the world are not properly analyzing to attain piece and unity and also to stop terrorism and all other natural calamities like, disasters and tsunami. Our research paper contains all kinds of solutions to solve world challenges and disputes.

\section{Holy books of Torah, Bible, Quran, Kalki Avatar}

\section{FIGURES AND TABLES}

\section{CONCLUSION}

Now 400 millions research papers are available for peace Solution, but there is no result for the it, unless the messages Posted in the website http://www.goldenduas.com are researched by researchers all over the world. Otherwise the world cannot have peace and Unity for some reasons or the other.

\section{Acknowledgements}

The research paper shall be acknowledged and the same may be published to all the researchers, publishers and all other community leaders, scholars for their opinions.

Examples follow:

\section{REFERENCES}

\section{Journal Papers:}

[1]. All the journal papers, internets, google, yahoo, facebook, twitter, android, cloud computing, sound cloud and also all the newspaper in the world.

Books:

[2]. R.E. Moore, Interval analysis (Englewood Cliffs, NJ: Prentice-Hall, 1966).

[3]. Note that the title of the book is in lower case letters and italicized. There is no comma following the title. Place of publication and publisher are given.

\section{Chapters in Books:}

[4]. Goldenduas

[5]. Note that the place of publication, publisher, and year of publication are enclosed in brackets. Editor of book is listed before book title.

Theses:

[6]. D.S. Chan, Theory and implementation of multidimensional discrete systems for signal processing, doctoral diss., Massachusetts Institute of Technology, Cambridge, MA, 1978.

[7]. Note that thesis title is set in italics and the university that granted the degree is listed along with location information

Proceedings Papers:

[8]. W.J. Book, Modelling design and control of flexible manipulator arms: A tutorial review, Proc. 29th IEEE Conf. on Decision and Control, San Francisco, CA, 1990, 500-506 